\title{
EU'S MULTIANNUAL FINANCIAL FRAMEWORK POST-2020: BREXIT IMPLICATIONS, WITH A FOCUS ON POLAND
}

\section{Abstract}

The aim of the paper is to critically analyse the main elements proposed in the EU's Multiannual Financial Framework (MFF) for 2021-2027 presented by the European Commission in May 2018 and the ways to solve the problem of the Brexit gap. The assessment of the effects of budgetary changes is focused on Poland. In order to achieve the research goals, we conduct a critical analysis of EU documents and a review of the literature.

Britain's exit from the EU may speed up the reform of EU budget revenue. The Brexit gap is so large that EU Member States, despite a general dislike of taxes at the EU level, may accept some of the EU proposals in order to bridge that gap. An increase in GNI-based contributions to the EU budget is also a very possible scenario. On the expenditure side of the budget, the new MFF provides for cuts in spending on agricultural and cohesion policies. As a very large beneficiary of such support at present, Poland will lose relatively the most. The compromise on funding the Brexit gap will significantly affect the EU's ability to finance its priority expenditure after 2021 and thus the possibility to cope with present and future integration challenges.

Keywords: Multiannual Financial Framework, Brexit, EU budget.

JEL Classification: E62, F15, F36, H49, H87.

Elżbieta Kawecka-Wyrzykowska, SGH Warsaw School of Economics, Collegium of World Economy, al. Niepodległości 162, 02-554 Warsaw, Poland, e-mail: ekawec@sgh.waw.pl, ORCID: https://orcid.org/0000-0002-6655-874X.

This is an open access article distributed under the terms of the Creative Commons AttributionNonCommercial-NoDerivatives 4.0 License (CC BY-NC-ND 4.0); https://creativecommons.org/ licenses/by-nc-nd/4.0/. 


\section{Introduction}

The EU's Multiannual Financial Framework (MFF) constitutes a key document specifying the maximum amounts of revenue and expenditure from the EU budget in a period of several years. Therefore, it determines the scale of measures funded at the EU level. The new MFF, to be effective from 2021, must take account of the possibility of the United Kingdom's exit from the EU (known as Brexit), which was postponed from 29 March 2019 until 31 October 2019 and then again until 31 January 20201. Brexit will bring about a reduction in both the UK's contributions to the EU budget and transfers to the UK economy. Since the country in question is the second biggest net payer to the EU budget, the decrease in EU budget revenue will be much greater than the decline in spending.

On 2 May 2018, the European Commission presented a package of documents containing a draft $\mathrm{MFF}$ and accompanying legislative proposals (http://ec.europa.eu/budget/mff/index2021-2027_en.cfm). It was preceded by a series of analytical documents presented in 2017 regarding various aspects of the EU budget and the future of the EU (https://ec.europa. $\mathrm{eu} /$ commission/publications/reflection-paper-future-eu-finances_en).

This article aims to critically analyse the main elements proposed in the MFF and to determine the European Commission's approach to adjusting the EU funding system for 2021-2027 to the United Kingdom's exit from the EU. The emphasis is on the scale of reductions in EU budget revenue after 2021 and on the ways of financing it as that part of the budget will be the most affected by Brexit. We also indicate selected proposals for reducing EU budget spending. The Commission's rationale is (partly) that savings need to be made because of Brexit. Furthermore, these proposals concern two areas which are currently the most significant sources of EU transfers to Poland, i.e. cohesion policy and the common agricultural policy (CAP), and their consequences will be very important for the Polish economy.

${ }^{1}$ There is no guarantee, however, that Brexit will actually happen. The withdrawal agreement of the UK from the EU was endorsed by EU leaders on 25 November 2018. The UK was due to leave on 29 March 2019, two years after it started the exit process by invoking Article 50 of Lisbon Treaty. The agreement was not, however, accepted by the British Parliament, whose approval is necessary for ratification. In fact, it was rejected several times by the House of Commons. On 11 April 2019, the European Council agreed - at the request of the British Prime Minister Theresa May - to an extension of the UK's exit from the EU until 31 October. However, at the end of 2019 there are still huge controversies over Brexit among British politicians and in British society. 
In order to achieve the research goals, we conduct a critical analysis of EU documents and a review of the literature.

The starting point for the analysis is an assessment of the importance of the multiannual budget to the implementation of EU priorities. This is followed by an estimation of the United Kingdom's current position in that budget and of the scale of funds necessary to finance the gap stemming from the UK's exit from the EU. In that context, the paper presents the Commission's proposals concerning the new MFF for 2021-2027. The findings refer to the implications of the discussed changes, mostly from the point of view of Poland.

\section{Importance of the Multiannual Financial Framework to the Process of European Integration}

Heated discussions between the EU institutions in connection with the adoption of annual budgets tend to attract significant interest from the public. But the fundamental role in EU actions is played by the Multiannual Financial Framework (MFF). In accordance with the Treaty on the Functioning of the European Union (TFEU), the MFF determines the size of the EU's annual budgets (Articles 310 to 320 of the TFEU). The current own resources ceiling in the budget (the appropriations with the reserve, referred to as the margin) is $1.23 \%$ of the EU-28 GNI (Council Regulation No 1311/2013). However, the ceilings on commitment appropriations and on payment appropriations as may be spent by the EU in the period covered by the MFF are lower. As regards the ceiling on commitment appropriations (i.e. funds for the implementation of EU policies, usually in a period longer than one year, after meeting certain conditions), in 20142020 it is an average of $1 \%$ of the EU-28 GNI, whereas the limit on payment appropriations (to be spent in a given year) is even lower - a mere $0.95 \%$ of the EU-28 GNI. The EU budget submitted for adoption must be in balance, i.e. show no deficit.

The Multiannual Financial Framework translates the EU policy priorities into budgetary amounts. Simultaneously, it is an instrument for maintaining budgetary discipline, since expenditures in annual budgets must be consistent with the MFF ceilings. Thanks to covering a period of several years (since the early 1990s - 7 years, whereas the TFEU provides for MFFs adopted for a minimum of 5 years), the MFF also ensures stability in the financing of EU actions: beneficiaries are able to project the level of such spending in subsequent years. 
The new MFF should enter into force at the beginning of 2021 as the current MFF expires at the end of 2020. Reaching a new financial compromise will be much more difficult than in the case of the current MFF for 2014-2020, e.g. due to the large revenue gap stemming from the anticipated exit of the United Kingdom from the EU, the new challenges faced by the EU, such as an enormous inflow of immigrants and refugees, the digital revolution, globalisation, demographic changes, socio-economic inequalities, climate change, etc. (European Commission 2017, p. 8). The talks were also slowed down by the European Parliament elections (in May 2019) and the resulting change in the composition of the European Commission, which started its work with a one-month delay, i.e. on 1 November 2019.

The legal basis for an MFF is a regulation adopted by the Council unanimously after obtaining the consent of the European Parliament (given by a simple majority of its component members). Negotiations on the whole package of financial provisions involve - according to the TFEU three institutions: the Council, the European Parliament and the European Commission. In practice, however, the key elements of the MFF are first established by the European Council.

\section{Threats to the MFF Post-2020 Resulting from Brexit}

The UK exit from the EU will result in a significant decline in EU budget revenue after 2020. In the agreement with the EU-27 of November 2018 (Agreement 2019, Art. 135) the United Kingdom agreed to continue to honour its financial obligations under the MFF for 2014-2020, even though it would probably earlier cease to be a Member State of the EU. In the case of a "no deal" exit from the EU (without an agreement), which cannot be excluded because of huge Brexit turmoil, the UK may decide to stop contributing to the EU budgets under the present MFF (i.e. in 2020 if Brexit is effective as of this year).

Due to the fact that the United Kingdom is now a major (the second largest) net payer, after its exit the decrease in EU budget revenue (in respect of the UK's payments) will be much greater than the decline in spending (transfers to the United Kingdom). Therefore, there is a risk that funds for EU-27 actions will be reduced from 2021 onwards.

In the literature there are varying estimations of the "Brexit gap" beyond 2020. The differences in these findings are primarily due to the adoption, as the basis for estimation, of different concepts of the EU annual budget, different years for estimation, and different calculation 
methodologies (specifically, the inclusion or exclusion of the UK rebate). For example, J. Haas and E. Rubio (2017, p. 1) estimate the yearly net gap amount (net of UK contributions to the EU budget) at EUR 10 billion; E. Kawecka-Wyrzykowska (2018, p. 5) - at EUR 16.5 billion (as an average calculated on the basis of data for 2014-2015); and I. Begg (2017, p. 2) - at EUR 17 billion (an annual average for the period 2013-2015), i.e. ca. 12\% of EU budget revenue. Each of the above-mentioned approaches shows a significant amount of funds missing from the budget after the United Kingdom's exit ${ }^{2}$. An obvious consequence of such a situation would be reducing appropriations for the financing of EU-27 actions in comparison with current spending. Therefore, an important question is whether the EU Member States will be able to agree on bridging the gap arising after 2020 or whether the EU budget will be reduced.

\section{Possible Financing of the Brexit Gap after 2021}

The proposal for a Council Decision on the system of own resources of the EU of 2 May 2018 provides for 1.29\% of the EU-27 GNI ceiling (in terms of payments; European Commission 2018d, p. 2). This is an increase compared with the present financial period and reflects the higher payment needs of the EU integration process on the one hand, and the proposal to finance the "Brexit gap" on the other. Without raising the ceiling on own resources (set as a percentage of the EU GNI), the absolute size of the EU-27 budget would fall after the withdrawal from the EU of the United Kingdom, a very significant Member State in terms of income (around 15\% of the EU GNI). In other words, leaving the own resources ceiling at $1.23 \%$ of GNI determined for the EU-28 for 2014-2020, after a decrease in the number of EU Member States and, therefore, a considerable fall in GNI, would result in a decline in the absolute value of the budget.

However, in 2021-2027, as at present, the commitment and payment appropriations will be lower than the ceiling on own resources. Those will be, respectively, $1.11 \%$ and $1.08 \%$ of GNI (current prices; European Commission 2018b, p. 25). According to the Commission, the above levels are comparable to the size of the current Financial Framework in real terms.

Obviously, every growth in the EU budget, or even only maintaining its level from the current period, after the revenue reduction in respect

${ }^{2}$ All these estimates have been done on the basis of the historical data of the EU budget. They do not take account of inflation, which will increase all items of the budget, including the size of the Brexit gap. 
of UK payments, must be reflected in an increase in revenue. As already mentioned, the EU budget must be in balance.

Aware of the reluctance of various Member States to accept any new burdens in the form of additional contributions to the EU budget, the European Commission proposed significant modifications in the financing of the budget (European Commission 2018b, p. 27). The main new elements, presented by the European Commission on 2 May 2018, provide for the introduction of a basket of the following three new own resources:

a) $20 \%$ of the Emissions Trading System (ETS) revenues: the ETS (set up in 2005) is a key tool of EU climate policy, conducted for years in order to reduce greenhouse gas emissions. Within the framework of this policy, a number of "allowances" are auctioned by Member States and purchased by companies to cover their greenhouse gas emissions. The system is already significantly harmonised at the EU level.

b) A $3 \%$ EU call rate to be applied to the new Common Consolidated Corporate Tax Base (CCCTB) to calculate companies' taxable profits in the EU, including the digital sector. The call rate would be phased in once the tax and necessary legislation has been adopted. This solution would link the financing of the EU budget directly to the benefits enjoyed by companies operating in the Single Market. Each Member State would be free to tax its share of the profits at its own national tax rate.

c) A national contribution calculated on the amount of non-recycled plastic packaging waste (a call rate of EUR 0.80 per kilo). The assumption is that this will create an incentive for Member States to reduce packaging waste and stimulate Europe's transition towards a circular economy by implementing the European plastics strategy.

When assessing the above proposals, it must be stated that the Commission chose such sources of revenue as would allow to better connect payments of specific entities with their benefits from the EU's single market. In some cases (proposals a) and c)) new resources would not only generate receipts to the budget but also foster the achievement of EU climate and environmental policy objectives, which are increasingly important. However, the effects on Member States would vary widely. For example, Poland's ETS-based payment would be relatively high (and likely to significantly increase the country's total contribution) owing to the Polish economy's considerable dependence on $\mathrm{CO}_{2}$ emissions and the high cost of purchasing additional greenhouse gas emission allowances by undertakings emitting $\mathrm{CO}_{2}$.

Altogether, the three new own resources could contribute EUR 22 billion per year, which corresponds to $12 \%$ of EU budget revenue. 
Moreover, simplification of the contributions based on current Value Added Tax is envisaged - they will be based on standard rates only ${ }^{3}$.

According to the Commission's proposal, the widely criticised rebates will disappear. On the United Kingdom's exit from the EU, there will be no more reason for the existence of the UK rebate and related rebates (i.e. reductions in its financing for Austria, Germany, the Netherlands and Sweden). As regards rebates connected with call rates for the VAT-based own resource and the lump sum reductions for contributions based on GNI, these will automatically expire at the end of 2020 . Let us note that such changes would bring about a significant increase in payments from the Member States currently benefiting from reductions ${ }^{4}$. Therefore, the Commission proposed the phasing out of the rebates over a period of 5 years.

According to the proposal for the MFF for 2021-2027, there will also be a reduction in the collection costs retained by Member States from traditional own resources (mainly from customs duties) from $20 \%$ to $10 \%$.

The Commission also emphasised that a swift political agreement on a new EU budget would be essential to demonstrate "that, following the withdrawal of the United Kingdom in 2019, the Europe of 27 is unified, has a clear sense of purpose and direction, and is ready to deliver. And it would give the best possible chance for new programmes to hit the ground running on schedule on 1 January 2021, turning political objectives into quick results on the ground" (European Commission 2018c, p. 18). In addition, as stressed by the Commission, an early agreement is important not only from the political but also from the practical point of view, as the EU funding will directly affect many beneficiaries and all of them need legal and financial certainty. Any delay in the adoption of the MFF will have negative implications for the launch of the new programmes and consequently to the achievement of funding priorities (European Commission 2018c, p. 18).

The Commission's position is naturally justified and correct but it will not be easy to achieve the adopted goals, not to mention a swift agreement. In practice, the proposal for a basket of new own resources of the budget means accepting new taxes at the European level. At first glance it seems that it should be positively assessed by EU Member States as it offers bigger financing of the EU budget, without an increased burden on

\footnotetext{
${ }^{3}$ Let us note that this is not a new proposal. It was already discussed in the early 2000 s, albeit in a somewhat different form - see, for instance, Cattoir (2004).

${ }^{4}$ The most affected Member State would be Germany, whose contribution to the EU budget would increase only in respect of the elimination of its "rebate on the United Kingdom rebate" by approx. EUR 1 billion per year (European Parliament 2016, p. 5).
} 
national budgets. The costs of additional funding would mostly be borne by enterprises (the CCCTB and ETS proposals) and consumers (the ETS and plastic packaging waste-based payments). However, many countries have "always" fought against any European tax, treating it as the strengthening of the powers of the Commission (as an institution over which the citizens have no control) and the weakening of national fiscal sovereignty and thus of political sovereignty as well. In previous years the Commission submitted various proposals for the introduction of a tax as a source of co-financing for the EU budget, but it was never successful in obtaining the Member States' consent. The difficulty in arriving at an agreement is that deciding on the system of own resources of the EU budget requires the Council to act unanimously and all the EU Member States to ratify such a decision (Article 311 of the TFEU). The chances are, however, that at least some of the Commission's tax proposals (or yet another tax) ${ }^{5}$ will be accepted, since this time the situation is different - a revenue gap of more than ten billion euros caused by Brexit and new challenges requiring extra financing.

Another option to cover the Brexit gap is to increase GNI-based payments. That would be the simplest solution in technical terms. This payment is a somehow automatic mechanism of national contributions (due to its residual character) ${ }^{6}$. Moreover, the method for calculating it is easy and transparent. The main problem is that the increase in GNI-based contributions would mean a very uneven financial burden on individual Member States. The countries to be hit hardest would be the present largest net contributors as they would become even bigger net payers to the EU budget. Such a solution would be politically unacceptable for those countries. A solution to mitigate this problem might be the introduction of new rebates (see: Kawecka-Wyrzykowska 2018, p. 6).

Failure to find appropriations for financing the gap would necessarily involve dramatic cuts in current budget items, including expenditure on cohesion and agriculture. Such reductions would have to be even sharper if the EU Member States intended to simultaneously increase spending on new priorities such as border protection and migration, youth mobility,

\footnotetext{
${ }^{5}$ The Commission itself presented the possibility of adding other sources of revenue in the form of seigniorage (revenue from the production of the euro that exceeded the cost of production of the euro) or revenues from the new European Travel Information and Authorization System (European Commission 2018a).

${ }^{6}$ The residual character of GNI-based resource means that it supplements revenue when the proceeds from traditional own resources and the VAT-based resource are not sufficient. National contributions of GNI resource are calculated according to the share of Member States in the EU GNI.
} 
environmental and climate protection, i.e. areas where the most significant growth in expenditure was proposed by the Commission. However, deep cuts in expenditure would give rise to strong objections by a number of countries which considerably benefit from the cohesion and agricultural policies.

Even before the submission of specific proposals by the European Commission in May 2018, the European Parliament took a position on the new MFF. This opinion is important as the Parliament must approve the MFF after its adoption by the Council, although it is not entitled to negotiate on the MFF or to modify the Council's arrangements. In its resolution of 14 March 2018, the EP stated as follows: "ahead of a decision on the post-2020 MFF, the 'Brexit gap' should be bridged while guaranteeing that EU resources are not reduced and that EU programmes are not affected negatively" (European Parliament 2018b, point 17). In practice, this means that the Parliament is not inclined to accept any deeper reductions in expenditure on the cohesion and agricultural policies.

\section{The Commission's Proposals for Savings in the EU Budget after 2020}

The financial package for 2021-2027 provides not only for new revenue resources (taxes) but also for savings. These apply to the two biggest types of expenditures from the EU budget: the common agricultural policy and cohesion policy.

In its Communication of February 2018, the Commission pointed to the positive role played by rural development programmes (European Commission 2018c, p. 12). With regard to direct payments, currently representing $70 \%$ of the CAP budget (with rural development and market intervention measures accounting for $25 \%$ and $5 \%$, respectively), the Commission stated that "Discussions are ongoing as to how to make best use of direct payments. Today, $80 \%$ of direct payments go to $20 \%$ of farmers".

Characteristically (certainly not incidentally), the Commission pointed out in its previous document from 2017 that "Apart from the rural development measures financed under the second pillar of the CAP, this is the only policy area managed together with the Member States without national co-financing" (European Commission 2017, p. 19). It may be interpreted as possible consideration of the national co-financing of payments in the new MFF. Such an option was explicitly mentioned by certain scholars and agricultural experts (e.g. Darvas \& Wolff 2018, p. 3; Begg 2017, p. 6).

In support of topping up direct payments, regional policy chief Corina Cretu stated that "National co-financing could be considered an option 
for direct payments" and added that "farmers don't mind whether CAP money comes from Brussels or the national coffers" (https://www. independent.ie/business/farming/eu/cap-under-pressure-as-most-memberstates-reject-cofinancing-of-direct-payments-35942698.html). However, Agriculture Commissioner Phil Hogan said that the vast majority of Member States opposed the idea of co-financing pillar I of the CAP.

Therefore, the idea of introducing the co-financing of direct payments is not purely theoretical. Poland is the sixth largest beneficiary of direct payments in 2014-2020 (Regulation (EU) No 1307/2013). Obviously, any decision on reducing the expenditure in question would involve a deteriorated income position of Polish farmers. At the same time, national co-financing of those payments would necessarily entail cuts in Polish budgetary spending on other important development objectives. However, we must emphasise that the Communication of 2 May 2018, i.e. the Commission's official proposal to be negotiated among the EU Member States, does not mention any national co-financing of direct payments.

According to the Commission's proposal, the reformed CAP will, with EUR 365 billion (European Commission 2018b, pp. 13, 29), account for $28.5 \%$ of the MFF commitments scheduled for 2021-2027. This means a reduction of around 5\% for the CAP budget at current prices (equivalent to a reduction of around $12 \%$ in constant 2018 prices) (http://europa.eu/ rapid/press-release_MEMO-18-3974_en.htm). Such cuts in CAP spending will substantially limit income support for farmers and funds aimed at improving the competitiveness of agricultural products.

As regards Poland, the proposal provides for EUR 30.5 billion (8.5\% of total spending on the common agricultural policy for the EU-27), of which nearly $70 \%$ will be for direct payments and $30 \%$ for rural development.

The Communication from the Commission assumes greater flexibility in the utilisation of appropriations at the disposal of Member States as they will have the option to transfer up to $15 \%$ of their CAP allocations between direct payments and rural development and vice-versa to ensure that national priorities and measures can be funded (http://europa.eu/rapid/pressrelease_IP-18-3985_en.htm). The Commission also proposed - undoubtedly under the influence of criticism from Member States, particularly those that joined the EU after 2004 - to reduce the differences in direct payments per hectare?

${ }^{7}$ The highest level of basic direct payments in the Netherlands and Belgium (excluding the unusual case of Malta with even higher payments) is around three times higher than in the Baltic states where it is the lowest. 
The new CAP will require farmers to better address environmental and climate goals. A portion of the direct payments will be conditional on enhanced environmental and climate requirements. Moreover, at least $30 \%$ of the rural development budget of each Member State will have to be dedicated to environmental and climate measures.

According to the Commission, the EU budget plays a crucial role in contributing to sustainable growth and social cohesion. In recent years, however, some regions have actually diverged, even in relatively richer countries $^{8}$. To better address the new situation, the Commission decided to extend the eligibility criteria for support to include new factors: labour market situation, education and demographics (15\% of the allocation of all funds); climate protection covering greenhouse gas emissions $(1 \%)$; migration factors, meaning net migration of non-EU citizens (3\%). The traditional gross domestic product (GDP) per capita level (GNI for the Cohesion Fund) will be responsible for $81 \%$ of the allocation of cohesion policy funds. Moreover, the national co-financing rates will be increased, which - in the Commission's opinion - will better reflect today's economic realities.

Out of EUR 373 billion (current prices, commitments) of cohesion policy appropriations in 2021-2027, Poland is supposed to receive EUR 72.7 billion, i.e. $19.5 \%$ of the sum total (http://europa.eu/rapid/press-release_IP-18-3885 en.htm). In contrast, in the 2014-2020 period, Poland has at its disposal EUR 77.6 billion (current prices) for reducing disparities in socio-economic development, i.e. $22 \%$ of the overall amount from the EU budget for that purpose (https://ec.europa.eu/regional_policy/en/information/publications/ factsheets/2014/cohesion-policy-and-poland). Therefore, the sum proposed is lower, especially in real terms (taking account of inflation). Nevertheless, in absolute terms, Poland will remain the largest beneficiary of cohesion policy in the EU.

Brexit may have yet another adverse effect on cohesion policy: certain regions will lose support. As a result of the United Kingdom's exit from the EU, there will be a fall in GDP per capita, which will decrease the eligibility threshold for support for the least wealthy regions. N. J. Brehon (2017) estimates that decline at ca. 3.6\%, i.e. around EUR 1,000. According

${ }^{8}$ Opinions among economists on the effectiveness of cohesion policy differ but a number of empirical studies confirm the positive effect of this policy on real convergence in the EU. Such convergence (in terms of GDP per capita in PPP, it is in purchasing power parity) is visible at the country's level, as the convergence between regions has been increasing since the deep recession in 2008 (on the review of academic literature relating to the effectiveness of cohesion policy see: Creel 2018). 
to his calculations, this statistical effect will cost $12 \mathrm{EU}$ regions their support entitlements. In that group, he also identified the Polish region of Wielkopolska (Brehon 2017, p. 18). Obviously, such regions are likely to get transitional solutions (the phasing-out of support), as was the case before when such situations occurred (e.g. as a result of previous EU enlargements). However, much will depend on the final decisions made, including on the scale of appropriations for that objective.

As cohesion policy plays an increasingly important role in supporting economic reforms in the Member States, the Commission proposed to strengthen the link between the EU budget and the European Semester of economic policy coordination. Let us note that the European Semester is about the enhanced coordination of national economic policies. Therefore, one can expect that the EU Member States will not easily accept the new proposal for making funding under cohesion policy conditional on the implementation of the European Semester priorities imposed by the Commission. But the Commission promised to prepare a "dedicated investment-related guidance alongside the annual Country-Specific Recommendations, both ahead of the programming process and at mid-term to provide a clear roadmap for investment in reforms that hold the key to a prosperous future" (European Commission 2018b, p. 9). However, there is still a risk that the proposed "guidance" will reduce the flexibility of cohesion policy spending in individual Member States.

Under the heading "Cohesion and values", the Commission also proposed increasing the stability and efficiency of the Economic and Monetary Union (EMU) and certain funds to pursue those goals. The rationale is evident. As the Commission argues: "Under the Treaties, the euro is the currency of the EU, and economic convergence and stability are objectives of the Union as a whole. This is why the tools to strengthen the Economic and Monetary Union must not be separate but part and parcel of the overall financial architecture of the Union" (European Commission 2018b, p. 10). For reasons of space, we shall not discuss this issue further here. Let us merely point out that those tools, albeit justified, will not be fully available to Poland as some of them are targeted at euro-area members only.

\section{Proposed Inclusion of the Conditionality Principle}

The Commission's proposal for the new post-2020 financial rules also included a suggestion as regards conditionality. This concerns the possibility to link the payment of budget appropriations to respect for 
the values referred to in Article 2 of the TEU, in particular with regard to the rule of law in Member States (European Commission 2018e). As indicated by the Commission, "under the current Multiannual Financial Framework, all Member States and beneficiaries are required to show that the regulatory framework for financial management is robust, that the relevant EU regulation is being implemented correctly and that the necessary administrative and institutional capacity exists to make EU funding a success". Simultaneously, the new MFF offers an opportunity to evaluate the implementation as well as "the moment to consider how the link between EU funding and the respect for the EU's fundamental values can be strengthened" (European Commission 2018c, p. 16). As a rule, such a mechanism could apply to all policies involving expenditure from the EU budget. The legal basis of a Regulation proposal is Article 322 of the Treaty on the Functioning of the EU, through which financial management rules are set ${ }^{9}$.

Under the proposal, the Union could suspend, reduce or restrict access to EU funding in a manner proportionate to the nature, gravity and scope of the deficiencies. This regulation could be invoked when a generalised deficiency as regards the rule of law in a Member State poses threats to, for instance, the proper functioning of the national authorities implementing the Union budget, effective judicial review by independent courts, the prevention and sanctioning of fraud, corruption or other breaches of EU law relating to the budget, the recovery of funds unduly paid, endangering the independence of the judiciary, failing to prevent, correct and sanction arbitrary or unlawful decisions by public authorities, the lack of implementation of judgements ${ }^{10}$. Thus, the coverage of the proposal is very broad. The proposed mechanism would not affect individual beneficiaries of EU funding under the budget, e.g. Erasmus students, researchers, etc. The argument is that they cannot be held responsible for breaches of law.

\section{Findings}

The decision on the next MFF funds will determine not only the Member States' approach to whether they wish to at least maintain the real size of the budget at the present level (which will require increasing revenue after the withdrawal of the United Kingdom) but, primarily, their choice

\footnotetext{
${ }^{9}$ The proposed idea of conditionality was supported by the European Parliament in its resolution of 14 March 2018 (European Parliament 2018c, point 4).

${ }^{10}$ Article 3 of the proposed regulation (European Commission 2018e).
} 
of a scenario for the EU's development in the nearest future. As aptly pointed out by J. Barcz, "in recent years, the internal differentiation of the Union has become a fact, a risk of fragmentation of the process of European integration, and a permanent characteristic of the process of European integration" (Barcz 2018, p. 31).

The above conducted analysis has demonstrated how much the future of an internally diverse EU now depends on reaching a compromise on increasing the budget for 2021-2027, at least by the Brexit gap. Without such a compromise, there will be insufficient funds to continue the current integration process, not to mention the new and ambitious priorities of the EU. A larger budget will mean readiness to jointly resolve existing and new problems and to enhance integration benefits. Limiting the budget to the size resulting from Brexit would mean having to reduce appropriations for currently implemented policies, especially the agricultural and cohesion policies, which represent important pillars of the process of European integration. The need to increase the budget is all the stronger that there are new objectives vital to all the EU Member States and whose effective implementation requires greater funds (e.g. counteracting climate change, the digitalisation revolution, the stabilisation of economic and monetary union, and external border protection).

The analysis has revealed that the United Kingdom's exit may speed up the reform of EU budget revenue. The Brexit gap is so large that net payers will object to financing it in technically the simplest but politically the hardest way - i.e. through a GNI increase. Therefore, they are likely to agree on new, additional sources, although not necessarily to approve all three of the Commission's proposals. It is also conceivable that a new rebate will be introduced as a compromise in the adoption of new solutions.

In 2021-2027, expenditure on cohesion policy and agriculture will be reduced. Such cuts would probably be inevitable anyway, but Brexit has made it easier for the Commission to justify them with the need for budgetary "savings" in conditions of lower revenue after 2020.

As in the case of other countries, Poland will receive less money from the EU budget after 2021 compared to 2014-2020. Cuts in funds for Poland (as well as for other Member States) will also result from other proposals of the Commission, only briefly mentioned here or excluded due to lack of space. For instance, those include the option to apply the conditionality principle (the reduction or suspension of EU funding in the event of a violation of EU values) in practice. Invoking such a provision is likely in situations where the Commission raises objections to Poland's 
deficiencies as regards the rule of law. Certainly, such a decision would be unfavourable for the country. Other conditions for possible cuts in EU funds for beneficiaries include decreasing the EU co-financing rate for projects funded under cohesion policy, the lack of access to all appropriations proposed for enhancing the stability of the euro area (some items are only targeted at euro-area members), etc. In other words, the sums resulting from the formal division of appropriations among Member States do not adequately reflect the scale of funds expected within the MFF for 20212027. The actual amounts will depend on meeting a number of detailed conditions.

\section{Acknowledgements and Financial Disclosure}

This paper is a result of statutory research project No. KGS/S17/10/2017 entitled "The future and challenges of the EU - implications of the United Kingdom's exit from the European Union", financed by the Ministry of Science and Higher Education of the Republic of Poland with the funds allocated to the Collegium of World Economy, SGH Warsaw School of Economics.

\section{Bibliography}

Agreement on the withdrawal of the United Kingdom of Great Britain and Northern Ireland from the European Union and the European Atomic Energy Community, OJ 2019/C 144 I/01.

Barcz, J. (2018) "Różnicujący się proces integracji europejskiej a Polska" in Polska w Unii Europejskiej. Nowe wyzwania. Warszawa: Komisja Europejska, Przedstawicielstwo w Polsce, pp. 29-36.

Begg, I. (2017) “The EU Budget after 2020”. SIEPS European Policy Analysis, September: $1-11$.

Brehon, N. J. (2017) "The Budgetary Impact of the Brexit on the European Union". European Issues 454: 1-17, Fondation Robert Schuman.

Cattoir, P. (2004) "Tax-based EU Own Resources. An Assessment". Working Paper 1: 1-47, European Commission.

Chomicz, E. (2017) "EU Budget Post-Brexit Confronting Reality, Exploring Viable Solutions. European Policy Centre Discussion Paper: 1-56.

Council Regulation (EU, EURATOM) No 1311/2013 of 2 December 2013 laying down the multiannual financial framework for the years 2014-2020, OJ 347, 20 December.

Creel, J. (2018) "Convergence in EMU: What and How? Analysis Requested by the European Parliament", pp. 1-32.

Darvas, Z. and Wolff, G. (2018) "Rethinking the European Union's Post-Brexit Budget Priorities”. Bruegel Policy Brief 1: 1-8. 
European Commission (2017) Reflection Paper on the Future of EU Finances, $\operatorname{COM}(2017) 358$ of 28 June 2017.

European Commission (2018a) EU Budget for the Future. Modernising the EU Budget's Revenue Side, 2 May.

European Commission (2018b) A Modern Budget for a Union that Protects, Empowers and Defends The Multiannual Financial Framework for 2021-2027, Communication from the Commission to the European Parliament, the European Council, the Council, the European Economic and Social Committee and the Committee of the Regions, Brussels 2.5, COM(2018)321.

European Commission (2018c) A new, modern Multiannual Financial Framework for a European Union that delivers efficiently on its priorities post-2020. The European Commission's contribution to the Informal Leaders' meeting on 23 February 2018, Communication to the European Parliament, the European Council and the Council, Brussels, 14.2, $\operatorname{COM}(2018) 98$.

European Commission (2018d) Proposal for a Council Regulation laying down the multiannual financial framework for the years 2021 to 2027, Brussels, 2.5, $\operatorname{COM}(2018) 322$.

European Commission (2018e) Proposal for a Regulation of the European Parliament and of the Council on the protection of the Union's budget in case of generalised deficiencies as regards the rule of law in the Member States, Brussels, 2.5.2018 $\operatorname{COM}(2018) 324$ final.

European Parliament (2016) The UK 'rebate' on the EU budget. An explanation of the abatement and other correction mechanisms, Briefing, February.

European Parliament (2018a) Resolution of 14 March 2018 on the next MFF: Preparing the Parliament's position on the MFF post-2020 (2017/2052(INI).

European Parliament (2018b) Resolution of 14 March 2018 on reform of the European Union's system of own resources (2017/2053(INI).

Haas J., Rubio, E. (2017) “Brexit and the EU Budget: Threat or Opportunity?" Jacques Delors Institute Policy Paper 183: 1-18.

Kawecka-Wyrzykowska, E. (2018) "Implications of Brexit for Financing of the EU Budget, with Particular Stress on the Effects on Poland". Unia Europejska.pl 1: 3-12.

Regulation (EU) No 1307/2013 of the European Parliament and of the Council of 17 December 2013 establishing rules for direct payments to farmers under support schemes within the framework of the common agricultural policy and repealing Council Regulation (EC) No 637/2008 and Council Regulation (EC) No 73/2009.

\section{Abstract}

\section{Wieloletnie ramy finansowe Unii Europejskiej po 2020 roku - skutki brexitu, ze szczególnym uwzględnieniem Polski}

Celem artykułu jest krytyczna analiza głównych elementów propozycji Wieloletnich ram finansowych (WRF) Unii Europejskiej na lata 2021-2027 przedstawionych przez Komisję Europejską w maju 2018 r., w tym dotyczących sposobów zaradzenia luce brexitowej. Ocena możliwych skutków zmian w budżecie UE uwzględnia głównie 
perspektywę Polski. Dla osiągnięcia celów badawczych zastosowano metodę analizy dokumentów unijnych i przeglądu literatury przedmiotu.

Wyjście Wielkiej Brytanii z UE może przyspieszyć reformę dochodów unijnego budżetu. Luka brexitowa jest tak duża, że państwa UE, mimo generalnej niechęci wobec podatków na poziomie UE, mogą zaakceptować niektóre ich propozycje w celu pokrycia tego niedoboru. Najprawdopodobniej nastąpi też pewne zwiększenie wpłat z tytułu DNB. Po stronie wydatków projekt nowych WRF przewiduje cięcia środków przeznaczonych na politykę rolną i spójności. Polska, będąca obecnie dużym beneficjentem środków na takie działania, straci na tym stosunkowo najwięcej. Kompromis w sprawie pokrycia luki brexitowej będzie miał istotny wpływ na zdolność sfinansowania po 2021 r. priorytetowych wydatków UE, a tym samym na możliwość sprostania obecnym i przyszłym wyzwaniom integracyjnym.

Słowa kluczowe: wieloletnie ramy finansowe, Brexit, budżet Unii Europejskiej. 